\title{
Genetic and Physical Mapping of the RPP13 Locus, in Arabidopsis, Responsible for Specific Recognition of Several Peronospora parasitica (Downy Mildew) Isolates
}

\author{
Peter Bittner-Eddy, Canan Can, Nick Gunn, Matthieu Pinel, Mahmut Tör, lan Crute, Eric B. Holub, \\ and Jim Beynon \\ Horticulture Research International, Wellesbourne, Warwick, CV35 9EF, U.K. \\ Accepted 19 May 1999.
}

Fifteen isolates of the biotrophic oomycete Peronospora parasitica (downy mildew) were obtained from a population of Arabidopsis thaliana plants that established naturally in a garden the previous year. They exhibited phenotypic variation in a set of 12 Arabidopsis accessions that suggested that the parasite population consisted of at least six pathotypes. One isolate, Maks9, elicited an interaction phenotype of flecking necrosis and no sporulation $(\mathrm{FN})$ in the Arabidopsis accession Nd-1, and more extensive pitting necrosis with no sporulation (PN) in the accession Ws2. RPP13 was designated as the locus for a single dominant resistance gene associated with the resistance in $\mathrm{Nd}-1$ and mapped to an interval of approximately $60 \mathrm{~kb}$ on a bacterial artificial chromosome (BAC) contig on the lower arm of chromosome 3 . This locus is approximately $6 \mathrm{cM}$ telomeric to $R P P 1$, which was previously described as the locus for the PN interaction with five Peronospora isolates, including resistance to Maks9 in Ws-2. New Peronospora isolates were obtained from four other geographically distinct populations of $\boldsymbol{P}$. parasitica. Four isolates were characterized that elicited an FN phenotype in Nd-1 and mapped resistance to the $R P P 13$ locus. This suggests that the $R P P 13$ locus contains either a single gene capable of multiple isolate recognition or a group of tightly linked genes. Further analysis suggests that the RPP11 gene in the accession RId-0 may be allelic to RPP13 but results in a different recognition capability.

Extensive natural genetic variation has been revealed in the interaction between accessions of the wild crucifer Arabidopsis thaliana and isolates of Peronospora parasitica, the biotrophic oomycete that causes downy mildew (reviewed by Holub 1997; Holub and Beynon 1997). This variation is mani-

Corresponding author: Jim Beynon; Telephone: (+44) 1789 470382; Fax: (+44) 1789 470552; E-mail: jim.beynon@ hri.ac.uk

Current address of Canan Can: University of Çukurova, Faculty of Agriculture, Department of Plant Protection, 01330, Adana, Turkey.

Current address of Ian Crute: Institute of Arable Crop Research, Rothamsted, Harpenden, Hertfordshire, AL25 2JQ, UK. fested phenotypically as differences in the amount of asexual parasite reproduction and in host response visible as different classes of necrosis (Holub et al. 1994). Simple inheritance has been observed for most sources of downy mildew resistance examined thus far, so a gene-for-gene relationship (Flor 1971) has been proposed as being a common feature of this wild pathosystem. In such a relationship, specific resistance genes in Arabidopsis correspond genetically with matching genes in P. parasitica (so-called avirulence genes) (Koch and Slusarenko 1990; Parker et al. 1993; Holub et al. 1994; Joos et al. 1996; Reignault et al. 1996). The current hypothesis is that the resistance gene protein provides molecular recognition of the invading parasite by interacting directly with the matching avirulence gene product, and that this recognition event somehow activates a defense response in the host. For Arabidopsis downy mildew, more than 20 loci for genes conferring specific recognition of $\underline{P}$. parasitica $(R P P)$ have been identified that are distributed among the five chromosomes of Arabidopsis (Holub 1997).

Several genotype-specific disease resistance genes have been isolated from Arabidopsis, including three genes for resistance to the necrotrophic bacterium Pseudomonas syringae (Mindrinos et al. 1994; Bent et al. 1994; Grant et al. 1995; Warren et al. 1998) and three downy mildew resistance genes (Parker et al. 1997; Botella et al. 1998; McDowell et al. 1998). DNA sequence comparison of these genes has revealed several common features: they all encode proteins predicted to reside within the cytoplasm, and they all include an N-terminal nucleotide binding site (NBS) motif and a C-terminal stretch of leucine rich repeats (LRRs). This molecular structure places them in the most frequently observed class of disease resistance genes identified thus far (reviewed by Hammond-Kosack and Jones 1997). LRRs are thought to be involved in protein-toprotein interactions (Kobe and Deisenhofer 1995) and variation in this region of resistance gene proteins may consequently determine specific recognition capability.

$R P P l$ is the first example of a complex locus in Arabidopsis that has been shown to contain a tightly linked family of genes ( $<1 \mathrm{cM}$ region) that differ functionally in their ability to recognize different isolates of $P$. parasitica (Botella et al. 1998). This provides an important analogy at least genetically to complex loci described previously in crop species such as 
the Rpl locus in maize and the Dm3 locus in lettuce (Hulbert 1997; Meyers et al. 1998). Single gene loci for disease resistance also occur in plants such as the classic example of an allelic series of differing resistance specificities at the $L$ locus in flax (Ellis et al. 1995, 1997). A true series of functionally different alleles has yet to be demonstrated in Arabidopsis; however, single gene loci have been identified at two bacterial resistance loci, RPM1 (Grant et al. 1995) and RPS2 (Bent et al. 1994; Mindrinos et al. 1994).

Molecular characterization of additional resistance genes from Arabidopsis is important to determine how widespread the NBS-LRR class of resistance genes is in the species and to investigate the relationship between sequence evolution and the function of resistance gene "alleles" in either simple or complex loci. Further examples may also reveal new classes of disease resistance genes, or genes in Arabidopsis similar to those found previously in other plant species, such as the serine/threonine kinase Pto gene from tomato (Martin et al. 1993), the leucine rich receptor kinase $\mathrm{Xa21}$ gene from rice (Song et al. 1995), and the $C f$ genes from tomato that encode extracellular, membrane-anchored, LRR proteins (Jones et al. 1994; Dixon et al. 1996; Thomas et al. 1997). We are particularly interested in determining whether a simple locus for an allelic series of downy mildew resistance exists in Arabidopsis.

We describe here a new locus designated $R P P 13$ that is approximately $6 \mathrm{cM}$ telomeric to the complex locus $R P P 1$ on chromosome 3 of Arabidopsis. Several new P. parasitica isolates from different wild populations are described that were used to map a resistance specificity to the RPP13 locus in the same resistant accession, $\mathrm{Nd}-1$. We also provide evidence that suggests that RPP13 may be allelic to the RPP11 locus described by Joos et al. (1996) in the Arabidopsis accession Rld0 , which confers resistance to an $\mathrm{Nd}-1$ compatible isolate.

\section{RESULTS}

Origin of a new $P$. parasitica isolate that identified $R P P 13$.

The new isolate, designated Maks9, that was used eventually to identify $R P P 13$, was one of several isolates that were collected from a private garden in Maidstone, Kent, UK. Iso- lates were sampled from the parasite population 1 year after downy mildew-infected plants were first observed in the garden. Arabidopsis itself had first appeared in the garden as a few plants in the previous year, suggesting a recent introduction of both the host and parasite. Leaf tissue containing oospores (sexual inoculum) was harvested from infected plants. All of the isolates were subsequently derived in the laboratory from root infections of seedlings by oospores with a single Arabidopsis accession (Ksk-1) as a bait (see Materials and Methods). Infections resulted in the production of conidiosporangia (asexual inoculum) in cotyledons, from which each isolate was cultured in the same accession for experimentation and long-term storage. Pathogenic variation among the isolates was determined by inoculating a geographically diverse set of Arabidopsis accessions and assessing phenotypic interactions for each combination of accession and isolate (Table 1). At least six different pathotypes were identified among the isolates. Maks9 was selected from the collection of isolates as one that was compatible in Col-5 (Fig. 1A) and incompatible in Nd-1 (Fig. 1B), enabling the use of an $\mathrm{F}_{9}$ recombinant inbred mapping population that was developed from a cross between these accessions (described below).

The isolate Maks9 was intriguing because the interaction phenotype it elicited in Nd-1 was markedly different from "pitting" necrosis, which was the only previously observed phenotype in Nd-1 elicited by other isolates such as Emoy2 and Hiks1 (Holub et al. 1994). Pitting necrosis (Fig. 1C) was described as a patch of necrotic cells $(>1 \mathrm{~mm})$ in cotyledons that can first be observed macroscopically as soon as 3 days after inoculation (dai), and that usually expands and collapses at the center into a so-called "pit" within 7 dai. A halo of chlorosis surrounding the necrotic pit is also common, but more pronounced in other accessions such as Ws-0 inoculated with Emoy2 (Holub et al. 1994). Microscopically, the formation of a pit appears to result from structural collapse of mesophyll cells below the site of penetration. Hyphal growth is difficult to observe by light microscopy because of the collapsed tissue and accumulation of phenolic compounds. It has, therefore, not been determined whether host cell death is selfpropagated beyond the penetration site where the parasite's

Table 1. Interaction phenotypes of 12 Arabidopsis accessions following inoculation with 15 isolates of Peronospora parasitica derived from the Maidstone oospore population

\begin{tabular}{|c|c|c|c|c|c|c|c|c|c|c|c|c|c|}
\hline \multirow{2}{*}{$\begin{array}{l}\text { Pathotype } \\
\text { group }^{\mathrm{a}}\end{array}$} & \multirow{2}{*}{$\begin{array}{l}P \text {. parasitica } \\
\text { isolate }\end{array}$} & \multicolumn{12}{|c|}{ Arabidopsis accessions } \\
\hline & & Ws-3 & Col-5 & Kin-1 & Ler-1 & RId-2 & Tsu-0 & Oy-0 & Ksk-1 & Di-0 & Ema-1 & Cnt-1 & Nd-1 \\
\hline 1 & Maks1 & $\mathrm{H}^{\mathrm{b}}$ & M & $\mathrm{H}$ & FR & $\mathrm{L}$ & $\mathrm{H}$ & $\mathrm{H}$ & $\mathrm{H}$ & $\mathrm{H}$ & FN & FN & FN \\
\hline \multirow[t]{2}{*}{2} & Maks14 & $\mathrm{H}$ & $\mathrm{H}$ & FR & FN & FN & $\mathrm{H}$ & $\mathrm{H}$ & $\mathrm{H}$ & $\mathrm{H}$ & FN & FN & FN \\
\hline & Maks 15 & $\mathrm{H}$ & M & FN & FN & FN & $\mathrm{H}$ & $\mathrm{H}$ & $\mathrm{H}$ & $\mathrm{H}$ & FN & FN & FN \\
\hline \multirow[t]{2}{*}{3} & Maks 19 & $\mathrm{H}$ & $\mathrm{L}$ & $\mathrm{M}$ & FN & FR & $\mathrm{H}$ & $\mathrm{H}$ & $\mathrm{H}$ & $\mathrm{H}$ & FN & FN & FR \\
\hline & Maks22 & $\mathrm{H}$ & FN & M & FN & FR & $\mathrm{H}$ & $\mathrm{H}$ & $\mathrm{H}$ & $\mathrm{H}$ & FN & FN & FR \\
\hline \multirow[t]{3}{*}{4} & Maks21 & $\mathrm{H}$ & FN & $\mathrm{L}$ & FR & FR & $\mathrm{H}$ & $\mathrm{H}$ & $\mathrm{H}$ & $\mathrm{H}$ & FN & FN & FN \\
\hline & Maks7 & $\mathrm{H}$ & FN & FN & FR & FR & $\mathrm{H}$ & $\mathrm{H}$ & $\mathrm{H}$ & $\mathrm{H}$ & FN & FN & FN \\
\hline & Maks4 & $\mathrm{H}$ & FN & FN & FN & FN & $\mathrm{H}$ & $\mathrm{H}$ & M & $\mathrm{M}$ & FN & FN & FN \\
\hline \multirow[t]{3}{*}{5} & Maks20 & PN & $\mathrm{H}$ & $\mathrm{L}$ & FR & $\mathrm{L}$ & $\mathrm{H}$ & $\mathrm{H}$ & $\mathrm{H}$ & $\mathrm{H}$ & PN & $\mathrm{CN}$ & FN \\
\hline & Maks6 & PN & $\mathrm{H}$ & FN & FN & $\mathrm{FN}$ & $\mathrm{H}$ & $\mathrm{H}$ & $\mathrm{H}$ & $\mathrm{H}$ & $\mathrm{CN}$ & $\mathrm{CN}$ & FN \\
\hline & Maks9 & PN & $\mathrm{H}$ & $\mathrm{FN}$ & FN & $\mathrm{L}$ & $\mathrm{H}$ & $\mathrm{H}$ & $\mathrm{H}$ & $\mathrm{H}$ & PN & $\mathrm{CN}$ & FN \\
\hline \multirow[t]{4}{*}{6} & Maks18 & PN & FN & FN & FN & $\mathrm{L}$ & $\mathrm{H}$ & $\mathrm{H}$ & $\mathrm{H}$ & $\mathrm{H}$ & $\mathrm{CN}$ & $\mathrm{CN}$ & FN \\
\hline & Maks12 & PN & FN & FN & FN & FN & $\mathrm{H}$ & $\mathrm{H}$ & $\mathrm{H}$ & nt & FN & FN & FN \\
\hline & Maks5 & PN & FN & FN & FN & FN & $\mathrm{H}$ & M & $\mathrm{H}$ & $\mathrm{H}$ & PN & $\mathrm{CN}$ & FN \\
\hline & Maks8 & PN & FN & FR & FR & $\mathrm{L}$ & $\mathrm{H}$ & M & $\mathrm{H}$ & $\mathrm{H}$ & PN & $\mathrm{CN}$ & FN \\
\hline
\end{tabular}

\footnotetext{
${ }^{a}$ Isolates were grouped based on the pattern of phenotypic interaction with a range of Arabidopsis accessions.

${ }^{\mathrm{b}} \mathrm{P}=$ expanding necrotic pits; $\mathrm{F}=$ minute necrotic flecks; $\mathrm{FR}=$ minute necrotic flecks with rare sporulation; $\mathrm{N}=$ no parasite sporulation; $\mathrm{L}=$ low parasite sporulation ( $<10$ sporangiophores per cotyledon); $\mathrm{H}=$ heavy sporulation ( $>1$ sporangiophores per cotyledon).
} 
growth has already been arrested, or from progressive hypersensitive response to hyphae that penetrate out to the periphery of the lesion. Parasite reproduction has never been observed in cotyledons that exhibit pitting necrosis. Genetically, pitting necrosis in cotyledons has thus far only been associated with simply inherited sources of downy mildew resistance that map to the RPPl complex locus on the bottom arm of chromosome 3 (Botella et al. 1998; Tör et al. 1994; M. Pinel and E. B. Holub, unpublished).

In contrast, Nd-1 cotyledons exhibit a discrete "flecking necrosis" following inoculation with Maks9 (Fig. 1B). Necrotic lesions in this interaction are still only barely visible macroscopically 7 dai because only a few host cells at most appear to respond to presence of the parasite. The parasite hypha appears to cease growth in the first or second mesophyll cell that it penetrates, and penetrated mesophyll cells are usually autofluorescent, suggesting an accumulation of phenolics (not shown). Asexual sporulation has never been observed in this interaction. Hence, this interaction phenotype will be referred to below by the abbreviation FN (flecking host response with no parasite sporulation) as previously designated by Holub et al. (1994). The Maks9-compatible accession Col-5 permits heavy asexual sporulation by the isolate ( $>20$ sporangiophores per inoculated cotyledon), without the appearance of a visible host cell response (Fig. 1A).

\section{The FN phenotype predicts a single, dominant resistance} gene linked to $G L 1$ and $R P P 1$ on chromosome 3 .

Eleven $F_{1}$ progeny from a cross between the Maks9susceptible accession Col-5 and the Maks9-resistant accession Nd-1 were inoculated with Maks9. They all exhibited an FN phenotype, suggesting that resistance to this isolate from $\mathrm{Nd}-1$ is a dominant trait (Table 2).

Segregation of the FN phenotypic class of resistance from $\mathrm{Nd}-1$ was examined further by inoculating an $\mathrm{F}_{2} \mathrm{Col}-5 \times \mathrm{Nd}-1$ population of seedlings with Maks9. The number of genes associated with the FN class was predicted by comparing the proportion of $F_{2}$ progeny in this class with the total number observed in classes that exhibited some degree of sporulation (Table 2). In this case, a model predicting a dominant allele at a single locus in Nd-1 that confers resistance to Maks9 could explain the observed data in a ratio of $\mathrm{FN}$ : ( $\mathrm{FL}$ and $\mathrm{H}$ ). We designated this locus as RPP13, and proof for the existence of this locus was established by fine-scale mapping (described below). This interpretation of the $\mathrm{F}_{2}$ data does not, however, explain the partial resistance observed as the nonparental low sporulation (FL) phenotype. If the prediction for $R P P 13$ is correct, then at least one additional locus must be proposed to explain the FL phenotype, either as single gene resistance from $\mathrm{Nd}-1$ that was masked by the stronger $R P P 13$ resistance or else as novel resistance resulting from a new combination of two or more genes from the two parent accessions. A precedent for novel digenic resistance has been reported in Arabidopsis for resistance to the black rot pathogen Xanthomonas campestris (Buell and Somerville 1997). The FL class was too infrequent to suggest a second Nd-1 gene that segregated independently from $R P P 13$. The possibility of linkage between a strong and a weak resistance gene was examined in the effort to map RPP13.

Tentative mapping of RPP13 to chromosome 3 was aided by the glabrous (no trichomes) parent Col-5, which carries a recessive mutation at the GLl locus $(g l l)$ on the upper arm of this chromosome (Hauge et al. 1993). Nd-1 carries the dominant allele at $G L 1$ and is, therefore, glabrate. Segregation data (not shown) indicate that the morphological marker and the predicted RPP13 resistance were not segregating independ-

Table 2. Phenotypic segregation of $F_{2}$ progeny from a cross between Arabidopsis accessions Col-5 and Nd-1 following inoculation with the Peronospora parasitica isolate Maks9

\begin{tabular}{|c|c|c|c|c|c|c|c|c|c|}
\hline \multirow{2}{*}{$\begin{array}{l}\text { Gen- } \\
\text { era- } \\
\text { tion }\end{array}$} & \multicolumn{3}{|c|}{$\begin{array}{l}\text { Interaction } \\
\text { phenotype }^{\mathrm{a}}\end{array}$} & \multicolumn{3}{|c|}{$\begin{array}{c}\text { One gene model } \\
\text { FN : }(\mathrm{L} \& \mathrm{H}) \text { ratio }\end{array}$} & \multicolumn{3}{|c|}{$\begin{array}{l}\text { Two independent } \\
\text { genes model } \\
\text { (FN \& L) : H ratio }\end{array}$} \\
\hline & FN & $\mathbf{L}$ & $\mathbf{H}$ & Ratio & $\chi^{2}$ & $P$ & Ratio & $\chi^{2}$ & $P$ \\
\hline $\begin{array}{l}\mathrm{F}_{1} \\
\mathrm{~F}_{2}\end{array}$ & $\begin{array}{c}11 \\
712\end{array}$ & $\begin{array}{c}0 \\
118\end{array}$ & $\begin{array}{c}0 \\
108\end{array}$ & $3: 1$ & 0.411 & $>0.5$ & $\begin{array}{l}15: 1 \\
12: 3\end{array}$ & $\begin{array}{l}44.36 \\
48.94\end{array}$ & $\begin{array}{l}<0.001 \\
<0.001\end{array}$ \\
\hline
\end{tabular}

${ }^{\mathrm{a}} \mathrm{F}=$ minute necrotic flecks; $\mathrm{N}=$ no parasite sporulation; $\mathrm{L}=$ low parasite sporulation ( $<10$ sporangiophores per cotyledon); $\mathrm{H}=$ heavy sporulation (>10 sporangiophores per cotyledon).

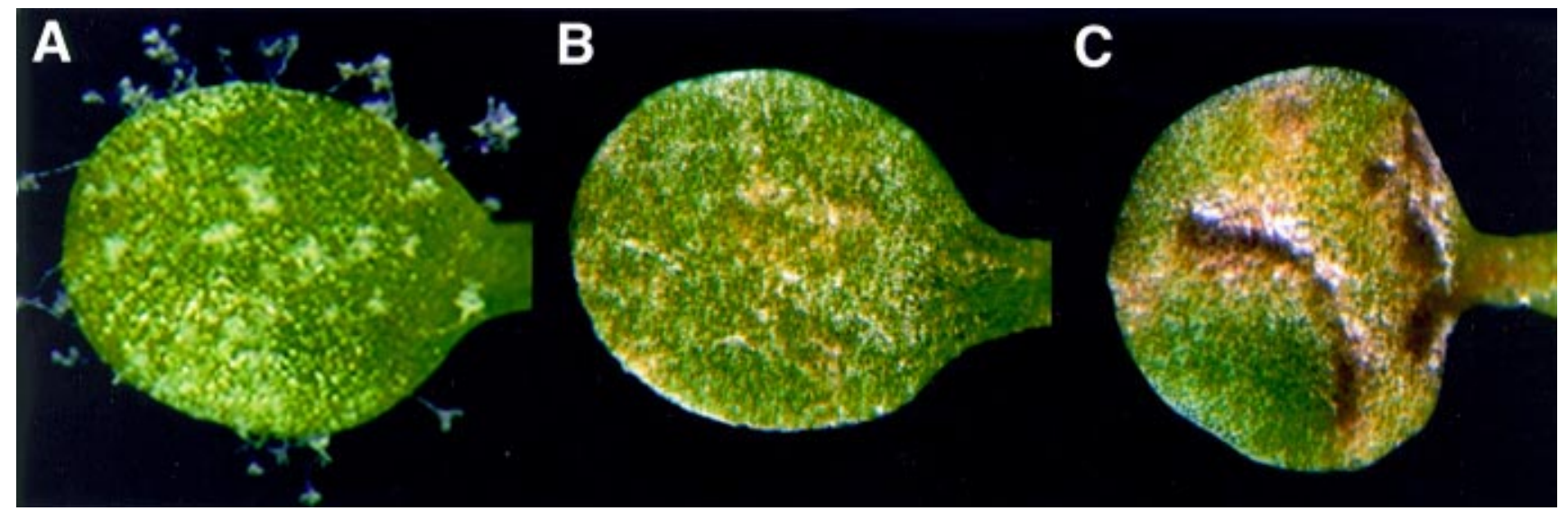

Fig. 1. Interaction phenotypes in cotyledons of Arabidopsis accessions (Col-5 or Nd-1) following inoculation with isolates of Peronospora parasitica (Maks9 or Emoy2). A, Fully compatible interaction between Col-5 and Maks9 characterized by heavy asexual sporulation of the parasite. B, Incompatible interaction between $\mathrm{Nd}-1$ and Maks9, characterized by discrete necrotic flecks and no sporulation. This resistance was associated genetically with a downy mildew resistance gene at the RPP13 locus. C, Incompatible interaction between Nd-1 and Emoy 2 characterized by expansive necrotic pits and no sporulation. This resistance was associated with a resistance gene at the RPP1 locus (see Holub et al. 1994). All of the cotyledons were 2 weeks old and were photographed 7 days after inoculation. 
ently among the seedlings because the observed ratio for two genes was significantly different from an expected 9:3:3:1 ratio. RPP13 was conclusively mapped to the bottom arm of chromosome 3 with marker data produced from a popula- tion of more than $100 \mathrm{~F}_{3}$ Col-5 $\times \mathrm{Nd}-1$ families (Fig. 2). These families were used previously to determine the $F_{2}$ genotype for downy mildew resistance at the RPPI locus (resistance to the isolate Emoy2 in Nd-1, described above), and to map this
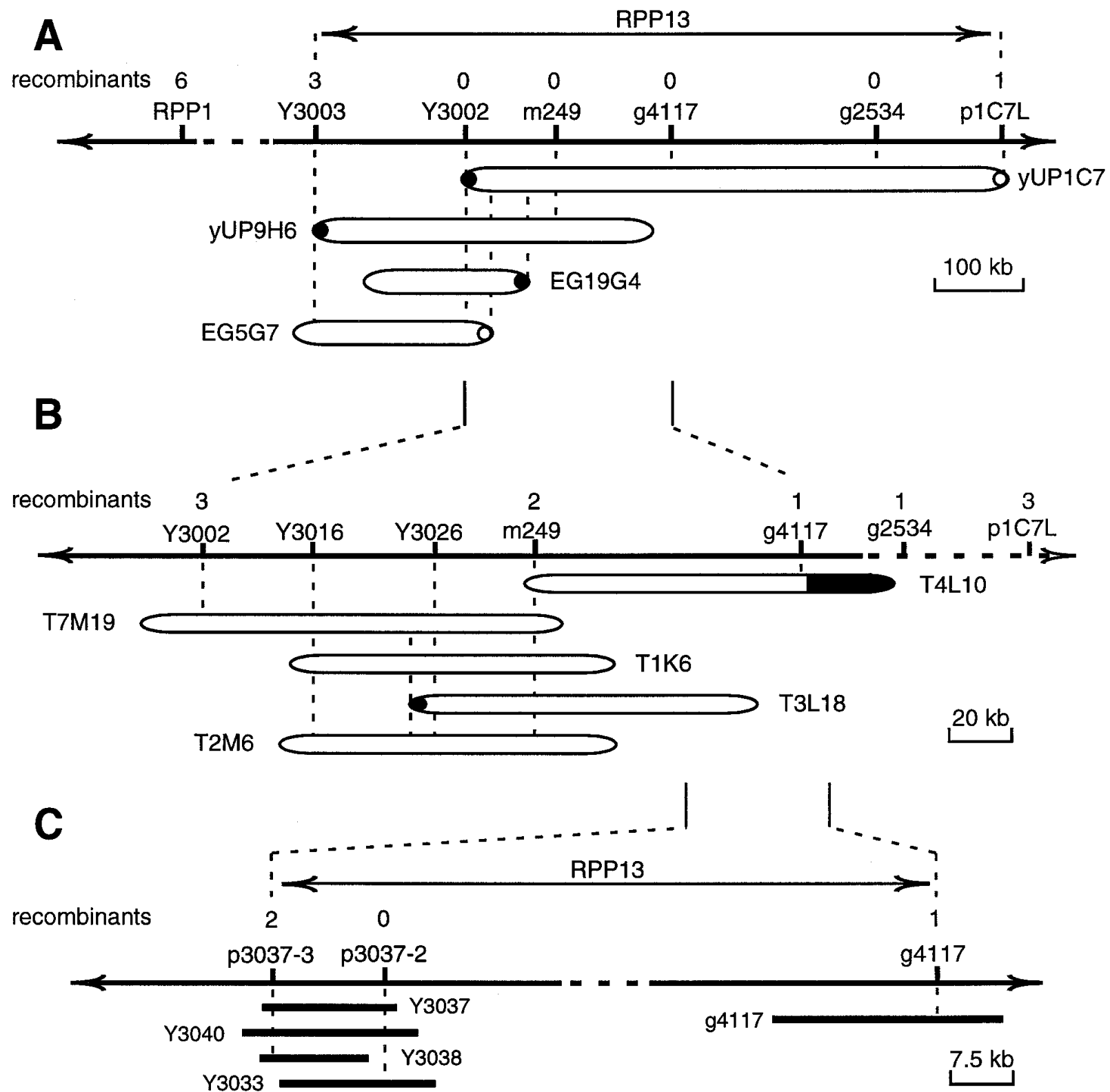

Fig. 2. Genetic mapping of the RPP13 locus and assembly of physical contigs. A, Restriction fragment length polymorphism (RFLP) and yeast artificial chromosome (YAC) clone contig map. Recombinant analysis of an $\mathrm{F}_{3}$ mapping population placed RPP13 between RFLP loci identified by clones Y3003 and p1C7L, some $6.6 \mathrm{cM}$ below RPP1. Number of recombinants identified in the $\mathrm{F}_{3}$ mapping population is given above the respective loci. YAC clones yUP1C7 and yUP9H6 were isolated with m249 and clones EG5G7 and EG19G4 with Y3002. YACs were anchored to the region by hybridization with existing molecular markers and to DNA fragments generated from their termini. Open and solid circles indicate DNA fragments successfully recovered from the left or right end of YAC clones, respectively. Size of YAC clones was determined by clamped homogeneous electric field (CHEF) gel electrophoresis. Number of recombinants refers to those found among the original $\mathrm{F}_{3}$ population. B, Bacterial artificial chromosome (BAC) clone contig map and recombinant analysis of the recombinant inbred (RI) lines and new $\mathrm{F}_{3}$ mapping populations. Number of recombinants identified in the new mapping populations is given above the respective loci. This analysis placed RPP13 between m249 and g4117. BAC clones were ordered by hybridization with existing molecular markers and by cross hybridization among themselves. Clones Y3016 and Y3026 were isolated from an Nd-1 DNA lambda library with the left end fragment of EG5G7 and right end fragment of EG19G4, respectively. BAC clone sizes were estimated from fragments released following digestion of DNA with HindIII. Black shading indicates noncontiguous region of chimeric clone T4L10. Number of recombinants refers to those identified among the RI lines and later selected $F_{3}$ families. C, Fine structure RFLP map. Nd-1 DNA lambda clones Y3033, Y3037, Y3038, and Y3040 were isolated with overlapping TAMU BAC clones T3L18 and T4L10. New RFLP markers p3037-2 and p3037-3 are subclones of Y3037. Recombinant analysis with these new markers placed RPP13 between RFLP loci identified by p3037-3 and g4117. Number of recombinants refers to those identified among the RI lines and later selected $\mathrm{F}_{3}$ families. Dashed lines indicate regions not drawn to scale. 
locus to a region on the bottom arm of chromosome 3, approximately $14 \mathrm{cM}$ below $G L 1$ and $6.6 \mathrm{cM}$ above the restriction fragment length polymorphism (RFLP) marker m249 (Tör et al. 1994). A sample of seedlings from the same $F_{3}$ families were inoculated with Maks9, and the predicted $F_{2}$ genotypes for alleles at RPP 13 co-segregated with m249 (data not shown). This evidence conclusively proved the existence of $R P P 13$, and placed it in close proximity to the complex locus for downy mildew resistance, $R P P 1$.

\section{Fine-scale mapping of $R P P 13$ to a region of less than $60 \mathrm{kbp}$.}

The molecular marker m249 was used as an anchor to determine a precise map interval for $R P P 13$ and to construct a physical map of the region. Two yeast artificial chromosome (YAC) clones were identified with this marker: yUP9H6 and yUP1C7, containing 375 and $600 \mathrm{kbp}$ of Arabidopsis DNA, respectively. DNA fragments from the termini of these YAC clones were isolated by vectorette amplification (see Materials and Methods). The amplification product from the left end of yUP1C7 was cloned to generate plasmid p1C7L. The right end fragments of yUP9H6 and yUP1C7 were used to isolate two lambda clones (Y3003 and Y3002, respectively) from a Ler-1 genomic DNA library. All three molecular markers (p1C7L, Y3003, and Y3002) were used to map RFLP loci to chromosome 3 with the existing $\mathrm{F}_{3}$ mapping population. This analysis placed RPP13 between Y3003 (above) and p1C7L (below), anchoring the locus to the region spanned by YAC clones yUP9H6 and/or yUP1C7 (Fig. 2A). New markers were acquired that mapped between $\mathrm{m} 249$ and the left end of yUP1C7 (based on published linkage maps; Chang et al. 1988; Nam et al. 1989; Lister and Dean 1993). However, RFLP loci revealed by clones g4117 and g2534 were not informative with the current $\mathrm{F}_{3}$ mapping population.

Additional Col-5 $\times \mathrm{Nd}-1$ offspring were produced from three sources to expand the mapping population and further refine the interval encompassing $R P P 13$. More than $2,000 \mathrm{~F}_{2}$ progeny of a Col-5 (rppl3/gll) $\times$ Nd-1 (RPP13/GL1) cross were inoculated with Maks9 and 180 individuals in two recombinant phenotypic classes (resistance/glabrous or susceptible/glabrate) were selected. $\mathrm{F}_{3}$ families were produced from these individuals and used for progeny testing of Maks9 resistance to determine the genotype of each $\mathrm{F}_{2}$ parent. These families were expected to provide recombinants on the centromeric side of $R P P 13$. An additional $150 \mathrm{~F}_{3}$ families were

Table 3. Three $\mathrm{F}_{9}$ Col- $5 \times$ Nd-1 recombinant inbred lines that exhibit partial resistance (low sporulation) that does not appear to correspond with the predicted RPP13 gene that maps to an interval on the bottom arm of chromosome 3 in Arabidopsis

\begin{tabular}{|c|c|c|c|c|c|c|c|c|c|}
\hline \multirow[b]{2}{*}{ Family } & \multirow{2}{*}{$\begin{array}{l}\text { Pheno- } \\
\text { type }^{\mathrm{a}}\end{array}$} & \multicolumn{8}{|c|}{ Loci defining the $R P P 13$ interval $^{b}$} \\
\hline & & RsaI & AciI & p3037-3 p & p3037-2 & $R P P 13$ & g4117 & g2534 & MseI \\
\hline 3895 & $3: 2: 12$ & 22 & 22 & 22 & 22 & ND & 22 & 22 & 22 \\
\hline 8019 & $27: 3: 0$ & 11 & 11 & 11 & 11 & ND & 11 & 11 & 11 \\
\hline 8067 & 19:9:0 & 11 & 11 & 11 & 11 & ND & 11 & 11 & 11 \\
\hline \multicolumn{10}{|c|}{$\begin{array}{l}\text { a Inoculated seedlings are recorded in a ratio of } \mathrm{N}: \mathrm{L}: \mathrm{H} \text { phenotype } \\
\text { classes: } \mathrm{N}=\text { no parasite sporulation, } \mathrm{L}=\mathrm{low} \text { amount of sporulation } \\
\text { ( }<10 \text { sporangiophores per cotyledon), and } \mathrm{H}=\text { heavy sporulation }(>20 \\
\text { sporangiophores per cotyledon. } \\
11=\text { homozygous for Col- } 5 \text { (maternal) allele; } 22=\text { homozygous for } \\
\text { Nd- } 1 \text { (paternal) allele; } 12=\text { heterozygous; } \mathrm{ND}=\text { could not be deter- } \\
\text { mined from phenotypic data. }\end{array}$} \\
\hline
\end{tabular}

produced from $\mathrm{F}_{2}$ individuals that were susceptible to Maks9 and glabrous, which we expected to include an enriched frequency of recombinants on the telomeric side of $R P P 13$ because no recombination had been selected on the other side. $\mathrm{F}_{9}$ recombinant inbred (RI) lines were also produced by single-seed descent from a random set of $\mathrm{F}_{2}$ Col- $5 \times \mathrm{Nd}-1$ individuals.

Analysis of the new $\mathrm{F}_{3}$ families and RI lines with the key molecular markers revealed a further six individuals with recombination breakpoints in the RPP13 mapping interval. Based on these new recombinant families, the $R P P 13$ locus was positioned between a co-dominant amplified polymorphic sequence (CAPS) locus identified by an $\mathrm{m} 249$ subclone (see Materials and Methods) and the RFLP locus identified by the clone g4117 (Fig. 2B).

Five BAC clones (T1K6, T2M6, T3L18, T4L10, and T7M19) were isolated by hybridization with $\mathrm{m} 249$ subclones and ordered by Southern hybridization with existing molecular markers, total BAC clone DNA, or DNA isolated from BAC ends (data not shown). The overlapping BAC clone contig encompassed $\mathrm{m} 249$ and g4117 and, therefore, spanned the RPP13 locus (Fig. 2B). T4L10, T3L18, and T2M6 were used sequentially as hybridization probes to identify clones from an $\mathrm{Nd}-1$ genomic DNA lambda library and to build a series of overlapping Nd-1 clones that mapped into the RPP13 interval. RFLP loci identified by Nd-1 lambda DNA clones unique to T4L10 were not linked with other loci on chromosome 3 , suggesting that clone T4L10 was a chimera. However, molecular markers developed from one (Y3037) of four lambda clones identified by both T3L18 and T4L10 were useful in further reducing the interval encompassing RPP13. The RFLP locus identified by subclone p3037-3 co-segregated with that of the m249 CAPS locus whereas the locus identified by subclone p3037-2 cosegregated with RPP13. Thus, RPPl3 was placed between p3037-3 (above) and g4117 (below) (Fig. 2C). Estimated from cross hybridization of BAC clones and the amount of DNA assembled in the Nd-1 lambda clone contig, the distance between p3037-3 and g4117 is no more than $60 \mathrm{kbp}$.

Attempts to isolate new clones from the $\mathrm{Nd}-1$ genomic DNA lambda library to bridge the gap between p3037-2 and g4117 were unsuccessful. Furthermore, no clones extending beyond p3037-2 and g4117 were found in additional Nd-1 or Col-0 genomic DNA lambda libraries, indicating that new Nd1 DNA clone libraries must be constructed.

In the course of mapping the RPP13 locus, three RI lines were identified that showed a nonparental interaction following inoculation with Maks9 (Table 3). These RI lines were characterized by apparent segregation of interaction phenotypes in addition to the occurrence of a nonparental FL phe-

Table 4. Interaction phenotypes of nine Arabidopsis accessions following inoculation with four isolates of Peronospora parasitica derived from four geographically different oospore populations

\begin{tabular}{lccccccccc}
\hline \multirow{2}{\text{Iso-}}{\begin{tabular}{l} 
late \\
\cline { 2 - 9 }
\end{tabular}} & Col-5 & Nd-1 & Ler-1 & Ws-3 & Oy-0 & Ksk-1 & C24 & Rld-0 & Wei-1 \\
\hline Aswal & H & FN & L & H & H & L & FN & FN & H \\
Edco1 & H & FN & FN & H & H & FN & FN & FN & M \\
Emco5 & H & FN & FN & H & FN & FN & FN & FN & H \\
Goco1 & H & FN & FN & H & FN & FN & FN & FN & M \\
\hline
\end{tabular}

${ }^{\mathrm{a}} \mathrm{F}=$ minute necrotic flecks; $\mathrm{N}=$ no parasite sporulation; $\mathrm{L}=$ low parasite sporulation ( $<10$ sporangiophores per cotyledon); $\mathrm{H}=$ heavy sporulation ( $>10$ sporangiophores per cotyledon). 
notype similar to that observed to segregate among $\mathrm{F}_{2}$ progeny of the Col-5 $\times$ Nd-1 cross (Table 2). Molecular analysis of these RI lines indicated no heterozygosity in the RPPI/13 region that might explain these observations. For RI lines 8019 and 8067 the FL phenotype could be explained by the presence of an additional locus recognizing the Maks9 isolate.

\section{RPP13 and the RPP11 locus from Arabidopsis accession RId may be alleles.}

RPP11 was first described by Joos et al. (1996) as a locus for resistance to the $P$. parasitica isolate Wela1, and mapped to the interval between $\mathrm{m} 249$ and g2534. A cross between the accessions Rld-0 (resistant) and Wei-0 (susceptible) was used to map this locus, which was shown to co-segregate with RFLP loci identified by g4117 and pN5 (a clone derived from the left end of YAC EG7H1). The marker pN5 was used to determine whether it mapped in the same interval as RPP13. This clone hybridized to BAC clones T3L18 and T4L10, which span RPP13 (data not shown). This suggests that a gene in Rld- 0 conferring resistance to the isolate Wela1 either is allelic with $R P P 13$ in $\mathrm{Nd}-1$ or, alternatively, is closely linked in an interval of no more than $60 \mathrm{kbp}$.

\section{Four additional $P$. parasitica isolates are recognized by a gene that maps to the $R P P 13$ locus.}

Four UK oospore populations, from different geographic regions, were sampled for $P$. parasitica isolates that were compatible on Col-5, incompatible on $\mathrm{Nd}-1$, and elicited an FN phenotype. These were used to identify additional isolates that may be recognized by a gene at the $R P P 13$ locus. Isolates that were collected included Aswa1, Emco5, Edco1, and Goco1 from Aspatria (Cumbria), East Malling (Kent), Edinburgh (Midlothian), and Godmersham (Kent), respectively. Each of the isolates was shown to be a unique pathotype by eliciting a different pattern of interaction phenotypes in a differential set of nine Arabidopsis accessions (Table 4). All four isolates were compatible with Col-5, enabling genetic analysis of resistance in Nd-1 with the mapping population that we had generated from the cross between Col-5 and Nd-1 (Table 5).

The segregation data indicated that a dominant allele at a single locus exists in Nd-1 associated with the FN interaction phenotype for resistance to Aswa1, Emco5, or Edco1. One hundred RI lines, including 3812 and 8065, that were informative recombinants for $R P P 13$ were used to establish the location of the resistance gene associated with the FN interac-

Table 5. Segregation of the FN interaction phenotype in progeny of a cross between Arabidopsis accessions Col-5 and Nd-1 following inoculation with four new isolates of Peronospora parasitica

\begin{tabular}{|c|c|c|c|c|c|c|c|c|c|}
\hline \multirow[b]{3}{*}{ Isolate } & \multicolumn{2}{|c|}{ Col-5 $\times$ Nd-1 } & \multirow{2}{*}{\multicolumn{4}{|c|}{$\begin{array}{l}\text { Interaction } \\
\text { phenotypes }^{\mathrm{a}}\end{array}$}} & \multirow{2}{*}{\multicolumn{3}{|c|}{ FN: non-FN ratio }} \\
\hline & \multirow{2}{*}{$\begin{array}{l}\text { Pheno- } \\
\text { type }\end{array}$} & \multirow{2}{*}{$\begin{array}{l}\text { Gener- } \\
\text { ation }\end{array}$} & & & & & & & \\
\hline & & & $\overline{\text { FN }}$ & $\mathbf{L}$ & $\mathbf{M}$ & $\mathbf{H}$ & Predicted & $\chi^{2}$ & $\mathbf{P}$ \\
\hline \multirow[t]{2}{*}{ Aswal } & $\mathrm{H} \times \mathrm{FN}$ & $\mathrm{F}_{1}$ & 12 & 0 & 0 & 0 & & & \\
\hline & & $\mathrm{F}_{2}$ & 641 & 102 & 58 & 21 & $3: 1$ & 3.74 & $>0.05$ \\
\hline \multirow[t]{2}{*}{ Emco5 } & $\mathrm{H} \times \mathrm{FN}$ & $\mathrm{F}_{1}$ & 18 & 0 & 0 & 0 & & & \\
\hline & & $\mathrm{F}_{2}$ & 517 & 100 & 55 & 12 & $3: 1$ & 0.10 & $>0.50$ \\
\hline Edcol & $\mathrm{M} \times \mathrm{FN}$ & $\mathrm{F}_{2}$ & 470 & 82 & 38 & 6 & $3: 1$ & 4.53 & $>0.01$ \\
\hline Gocol & $\mathrm{H} \times \mathrm{FN}$ & $\mathrm{F}_{1}$ & 6 & 0 & 0 & 0 & & & \\
\hline
\end{tabular}

${ }^{\mathrm{a}} \mathrm{F}=$ minute necrotic flecks; $\mathrm{N}=$ no parasite sporulation; $\mathrm{L}=$ low parasite sporulation $(<10$ sporangiophores per cotyledon); $\mathrm{H}=$ heavy sporulation ( $>10$ sporangiophores per cotyledon). tion phenotype following inoculation with each of the new isolates. Recombination frequencies between these $R P P$ genes and markers on all five Arabidopsis chromosomes were calculated (Table 6). No recombination was observed between RPP13 and the loci recognizing Aswa1, Emco5, Edco1, and Goco1. This suggested that these isolates are recognized by a gene at the same locus as Maks9 resistance, previously designated $R P P 13$.

Interestingly, the nonparental FL interaction phenotype observed among some of the $\mathrm{F}_{2}$ Col- $5 \times \mathrm{Nd}-1$ progeny following inoculation with Maks9 (Table 2) was again observed with each of the new isolates. However, inoculations of RI lines with Maks9 and the new isolates suggested that different genes may be responsible for the FL phenotype observed with each of the isolates (data not shown).

\section{DISCUSSION}

The $P$. parasitica isolates that were sampled from the Kentish garden population of Arabidopsis plants exhibited pathogenic variation when characterized by their phenotypic interactions in a set of 12 accessions (Table 1), suggesting that the parasite population consisted of at least six pathotypes. The host population had only been present in the garden for 2 years, with downy mildew first observed in the second year; hence, the source of heterogeneity in the parasite population presumably resulted from heterozygosity at avirulence loci in a single progenitor genotype and/or from multiple progenitor genotypes when first established in the garden. Although the

Table 6. Recombination frequency among $100 \mathrm{~F}_{9}$ Col-5 $\times \mathrm{Nd}-1$ recombinant inbred lines between the RPP loci defined by four Peronospora parasitica isolates and loci defined by molecular markers from the five Arabidopsis chromosomes

\begin{tabular}{|c|c|c|c|c|c|c|c|c|c|}
\hline \multirow{3}{*}{$\begin{array}{l}\text { Chro- } \\
\text { mosome }\end{array}$} & \multirow[b]{3}{*}{ Locus } & \multicolumn{8}{|c|}{$P$ parasitica isolate } \\
\hline & & \multicolumn{2}{|c|}{ Aswa1 } & \multicolumn{2}{|c|}{ Emco5 } & \multicolumn{2}{|c|}{ Edco1 } & \multicolumn{2}{|c|}{ Goco1 } \\
\hline & & $\mathbf{F}^{\mathbf{a}}$ & $\% \mathbf{r}^{\mathbf{b}}$ & $\mathbf{F}$ & $\% \mathbf{r}$ & $\mathbf{F}$ & $\% \mathbf{r}$ & $\mathbf{F}$ & $\% \mathbf{r}$ \\
\hline \multirow[t]{3}{*}{1} & $n c c 1^{\mathrm{c}}$ & 89 & 44 & 89 & 44 & 89 & 44 & 89 & 44 \\
\hline & gapB & 93 & 46 & 93 & 46 & 93 & 46 & 93 & 46 \\
\hline & nga280 & 92 & 43 & 92 & 43 & 92 & 43 & 92 & 43 \\
\hline \multirow[t]{3}{*}{2} & m246 & 87 & 36 & 87 & 36 & 87 & 36 & 87 & 36 \\
\hline & gpal & 72 & 51 & 72 & 51 & 73 & 51 & 73 & 51 \\
\hline & nga168 & 90 & 40 & 90 & 40 & 89 & 44 & 89 & 44 \\
\hline \multirow[t]{3}{*}{3} & GL1 & 85 & 17 & 85 & 17 & 85 & 17 & 85 & 17 \\
\hline & m249-A & 100 & 1 & 100 & 1 & 100 & 1 & 100 & 1 \\
\hline & $R P P 13$ & 100 & 0 & 100 & 0 & 100 & 0 & 100 & 0 \\
\hline \multirow[t]{2}{*}{4} & g3883 & 80 & 50 & 80 & 50 & 80 & 49 & 81 & 49 \\
\hline & $R P P 4$ & 98 & 52 & 98 & 52 & 98 & 52 & 98 & 52 \\
\hline \multirow[t]{3}{*}{5} & nga225 & 77 & 58 & 77 & 58 & 76 & 62 & 76 & 62 \\
\hline & nga76 & 82 & 42 & 82 & 42 & 82 & 42 & 82 & 42 \\
\hline & nga129d & 88 & 27 & 88 & 27 & 88 & 27 & 88 & 27 \\
\hline
\end{tabular}

${ }^{a}$ Number of $F_{9}$ inbred families evaluated.

${ }^{\mathrm{b}}$ Recombination percentage calculated as $\mathrm{r} \%=R 100 / 2(1-R)$, where $R$ is the recombination fraction (number of recombinant families divided by the total number of families evaluated).

c nccl, gapB, gpal, and GL1 are co-dominant amplified polymorphic sequence (CAPS) markers (Konieczny and Ausubel 1993); nga280, nga168, nga225, nga76, and nga129 are microsatellite markers (Bell and Ecker 1994); m246 (Chang et al. 1988) and g3883 (Nam et al. 1989) are restriction fragment length polymorphism (RFLP) markers; $\mathrm{m} 249-\mathrm{A}$ is a CAPS molecular marker derived from $\mathrm{m} 249$ (this work); $R P P 4$ is an Arabidopsis locus involved in recognition of the P. parasitica isolate Emwal (Tör et al. 1994).

${ }^{\mathrm{d}}$ Data for nga129 are skewed in this sample of inbred lines (Deslandes et al. 1998). 
isolates we collected were self-fertile in the laboratory, outcrossing among genotypes could in fact be quite common in nature. In any case, the pathogenic variation we observed suggests that $P$. parasitica can be a highly variable parasite of Arabidopsis.

Cotyledons of Arabidopsis accession Nd-1 exhibit a resistance response following inoculation with $P$. parasitica isolate Maks9 that is characterized by localized necrotic flecks on the host tissue and no pathogen reproduction (FN). The locus, designated $R P P 13$, responsible for this resistance response was mapped to the lower arm of chromosome 3 , closely linked to molecular marker $\mathrm{m} 249$. Investigations with an $\mathrm{F}_{3}$ mapping population established that RPP13 was linked to but genetically distinct from another Nd-1 disease resistance locus, RPPl (Tör et al. 1994; Botella et al. 1998). Recently, a physical map based on overlapping YAC clones has been published for chromosome 3 (Camilleri et al. 1998). From this map the distance between the two disease resistance loci can be estimated at between 1 and $1.5 \mathrm{mbp}$. When challenged by specific $P$. parasitica isolates, genes at the $R P P 1$ locus result in an interaction phenotype characterized by a spreading lesion (or pit) with no pathogen sporulation (PN). It is interesting that the loci $R P P 1$ and $R P P 13$, closely linked in the same accession of Arabidopsis, result in such different interaction phenotypes. Furthermore, the Maks9 isolate is recognized in Arabidopsis accession Ws-2 by a gene at the RPP1 locus (resulting in a PN interaction phenotype), instead of a gene at the RPP13 locus. This implies that there is a fundamental difference in the way in which the products of these loci interact with a particular $P$. parasitica isolate. The underlying mechanism of resistance could be the same but there may be a different timing/affinity related to the specific avirulence/resistance gene products involved. In practical terms, resistance responses resulting in a minimum of plant host tissue damage are desirable and an understanding of the mechanisms underlying these phenotypic differences, outlined above, will be critical to reliably achieving this goal with novel "engineered" genes.

A precise genetic map interval of the RPP13 locus was defined by developing a population of $\mathrm{F}_{9} \mathrm{Col}-5 \times \mathrm{Nd}-1 \mathrm{RI}$ lines and two $\mathrm{F}_{3}$ populations, selected on the basis of recombination (or lack of recombination) between the phenotypic markers $R P P 13$ and $g l-1$. These new resources allowed the RPP13 locus to be positioned in an interval defined by the RFLPs detected with genomic clones p3037-3 and g4117. An overlapping contig of BAC clones, carrying Col-0 genomic DNA, was assembled in this region. This allowed the interval between the two markers flanking $R P P 13$ to be estimated at no more than $60 \mathrm{kbp}$. An Nd-1 lambda genomic library was produced to establish a clone contig of Nd-1 DNA, as a key step in the cloning of RPP13. Exhaustive attempts, with several Nd-1 and Col-0 libraries, failed to create small clone contigs and only $25 \mathrm{kbp}$ of the $60 \mathrm{kbp}$ interval was covered. It therefore proved impossible to identify Nd-1 DNA clones within the interval. Further progress will require a new Nd-1 DNA library to be constructed, taking into account the obvious inherent difficulties in cloning DNA from this region. New markers will be useful in redefining the lower limit of the RPP13 interval, currently defined by g4117.

Evidence from studies with several $P$. parasitica isolates indicated that specific recognition of at least four isolates, in addition to Maks9, maps to the RPP13 locus. Several differ- ent, though not mutually exclusive, explanations may account for these observations. The simplest explanation would be that a single resistance gene recognizes the product of the same avirulence gene product common to all isolates. Alternatively, a single resistance gene may be capable of recognizing different avirulence gene products from more than one isolate. In this latter case, the resistance gene product may act directly as a receptor binding different avirulence gene ligands or, alternatively, may be a component of a common signaling pathway.

A precedent for dual recognition specificity was demonstrated by the RPMI gene from Arabidopsis, which encodes an NBS-LRR type protein that is capable of responding to two different bacterial avirulence gene products (from $P$. syringae pv. maculicola and $P$. syringae pv. glycinea) (Bisgrove et al. 1994; Grant et al. 1995). Interestingly, although either avirulence gene product will trigger a hypersensitive response in plants carrying $R P M 1$, there are qualitative differences in the reaction that may reflect differences in the binding affinities of each product and/or the timing of the disease resistance response (Bisgrove et al. 1994). Currently, the study of $P$. parasitica genetics is in its infancy and nothing is yet known about the number of avirulence gene products interacting with the $R P P 13$ locus and whether different isolates share functionally identical avirulence genes. Producing crosses between $P$. parasitica isolates and studying the segregation of avirulence will address these questions.

The further possibility, to account for the observation that several isolates are recognized by a gene or genes at the same locus, is that the RPP13 gene is one member of a multi-gene family, with different members recognizing different isolates. Clustering of resistance gene specificities has been suggested in Arabidopsis (Holub and Beynon 1997) and cloned RPP genes that have been used as molecular probes have revealed clustered multi-gene families, including the complex locus $R P P 1$, which was demonstrated to contain at least four gene members that varied functionally in recognition of different $P$. parasitica isolates (Parker et al. 1997; Botella et al. 1998). However, there was no evidence to suggest that repeated DNA, indicative of a clustered multigene family, exists within the estimated 60-kbp interval encompassing the RPP13.

During the course of mapping the RPP13 locus, three RI lines were identified that exhibited nonparental interaction phenotypes following inoculation with Maks9 even though the molecular genotypes of these lines were unambiguous (Table $3)$. There are several hypotheses that can account for these observations. First, a second resistance gene may exist in Nd-1 that, in the appropriate background, (i.e., in combination with one or more genes from Col-5) can provide partial resistance to Maks9. This second locus may have been revealed in inbreds 8019 and 8067, where a degree of incompatibility was observed, while the molecular data indicated that they would be expected to be compatible with Maks9. Among $\mathrm{F}_{2}$ progeny of the Col-5 $\times \mathrm{Nd}-1$ cross a nonparental FL interaction phenotype was observed following inoculation with Maks9. Cosegregation between RPP13 in 8019 and 8067 and an RFLP locus $14 \mathrm{cM}$ below p3037-2 (data not shown) suggests that if a second locus does exist it is not tightly linked to RPP13. An alternative interpretation for the occurrence of the FL phenotype is that it results from a combination of complementary genes provided by the Col-5 and $\mathrm{Nd}-1$ parents and present in RI lines 8019 and 8067. 
In Arabidopsis, novel digenic resistance to Xanthomonas campestris arising from recombination of genes from two accessions has been described (Buell and Somerville 1997). Homozygosity of RI lines was essential for fine-scale genetic definition of these loci in a population that was also segregating for another single gene resistance to the same bacterial isolate. We have also found evidence to suggest that resistance can be expressed to a number of $P$. parasitica isolates when it is absent from both parents, as a result of creation of novel gene combinations (N. Gunn and E. B. Holub, unpublished). A much larger population size and greater marker definition than currently exist will be required to establish whether the FL phenotype seen in RI lines 8019 and 8067 is attributable to another resistance gene(s) from Nd-1 gene or to a novel combination of genes from both Col-5 and Nd-1. Molecular analysis of RI line 3895 revealed that this family was homozygous for Nd-1 DNA throughout the interval containing the RPP13 locus and yet the interaction phenotype with Maks9 was nonparental and partially compatible. Maks9 has never been observed to sporulate in $\mathrm{Nd}-1$, suggesting that there may have been some local genetic rearrangement at the RPP13 locus in 3895 , such as unequal crossing-over, intramolecular recombination, or gene conversion. The molecular basis for this apparent anomaly may be established following the cloning of RPP13.

Molecular analysis with markers that co-segregate with RPP11 in Rld-0 (Joos et al. 1996) suggests that RPP11 and $R P P 13$ may be allelic. If the $R P P 13$ locus contains a single gene and it is allelic with $R P P 11$, then it would be the first example of a simple locus for functionally variable alleles of downy mildew resistance genes in Arabidopsis. Simple loci have been described previously in Arabidopsis for resistance to bacteria, but allelic variation for different functional specificities has not been demonstrated (Grant et al. 1995; Bent et al. 1994; Mindrinos et al. 1994). Functional variability at multi-gene loci has already been observed at the RPPI locus (Tör et al. 1994; Botella et al. 1998). Hence, RPP13 could be another example of such a locus but there is no evidence of repetitive DNA within the mapping interval. True allelic series have been described previously in other pathosystems such as the Mla locus in barley (Jørgensen 1992) and the $L$ locus of flax, where 13 different resistance specificities to flax rust (Melampsora lini) have been reported (Islam and Shepherd 1991). Cloning the RPP13 gene will probably enable isolation of RPP11. Comparison of the protein sequences of the RPP11 and $R P P 13$ gene products may be instructive in revealing amino acids residues that determine the recognition capability of Wela by RPP11 but not RPP13. Further analysis of such an allelic series could provide clues to the evolution of the ability to detect pathogens by disease resistance genes.

\section{MATERIALS AND METHODS}

\section{Cultivation and pathogenicity testing}

of $\boldsymbol{P}$. parasitica isolates in Arabidopsis.

The methods used to collect $P$. parasitica isolates from oospore inoculum, propagate asexual cultures, and inoculate Arabidopsis seedlings for experiments have been described previously (Dangl et al. 1992; Holub et al. 1994). All of the isolates were derived from oospore infection of Arabidopsis seedlings. The oospore inoculum was obtained from dried leaves of downy mildew-infected Arabidopsis plants that were found in wild populations. The isolates were named according to the convention proposed in Dangl et al. (1992), in which the first two letters of the name indicate where the inoculum was collected and the last two letters indicate a compatible host accession that can be used to maintain the isolate. Isolates produced from the same oospore population and maintained on the same host were given a distinguishing number. For example, Maks1 and Maks9 both came from the Maidstone oospore population and were maintained on the Arabidopsis accession $\underline{\text { Ksk}}-1$, but were derived from different oospore-infected seedlings.

The Arabidopsis accessions C24 and Kin-1 were obtained in 1991 from the Kranz collection. The origins of other Arabidopsis accessions used in this study have been described previously (Holub et al. 1994). Seed from all of these accessions is currently available from the Nottingham Arabidopsis Stock Centre (UK).

\section{Production of $\mathrm{F}_{3}$ and $\mathrm{F}_{\mathbf{9}}$ Col-5 $\times$ Nd-1 lines for mapping.}

Closed flower buds of the female parent were emasculated with the aid of forceps and pollination was performed by brushing the exposed stigmas with dehiscing anthers from the male parent. The resulting $\mathrm{F}_{1}$ seeds were collected and stored at $4^{\circ} \mathrm{C}$. Col-5 $(\mathrm{gll})$ was used as the female parent in the outcross to $\mathrm{Nd}-1$, thus allowing hybrid $\mathrm{F}_{1}$ seeds to be readily distinguished by the restored glabrate phenotype before selfing to produce $\mathrm{F}_{2}$ populations.

The $\mathrm{F}_{3}$ Col- $5 \times \mathrm{Nd}-1$ families were produced by selfing $\mathrm{F}_{2}$ individuals. The $\mathrm{F}_{9} \mathrm{RI}$ lines were produced by selfing followed by single seed descent to produce the next generation. Some of the RI lines were produced from an outcross between Col-3 (glabrate Columbia) and Nd-1. These lines and related marker data have been deposited in the Nottingham Arabidopsis Stock Centre (UK).

\section{Nd-1 DNA lambda library.}

Approximately $10 \mathrm{~g}$ of leaf tissue was ground to a fine powder with a mortar and pestle in liquid nitrogen. The powder was thawed in $15 \mathrm{ml}$ of extraction buffer $(2 \%$ [wt/vol] hexadecyltrimethylammonium bromide [CTAB], $1.4 \mathrm{M} \mathrm{NaCl}$, $100 \mathrm{mM}$ Tris- $\mathrm{HCl} \mathrm{pH} 8.0,20 \mathrm{mM}$ EDTA, 0.2\% [vol/vol] 2-mercaptoethanol) and incubated at $65^{\circ} \mathrm{C}$ for $1 \mathrm{~h}$. The suspension was extracted with an equal volume of chloroform: octanol (24:1) and the resulting aqueous phase mixed with $1 / 10$ volume of pre-warmed $\left(65^{\circ} \mathrm{C}\right) \mathrm{CTAB} / \mathrm{NaCl}$ solution $(10 \%$ [wt/vol] CTAB, 0.7 M NaCl). Following a second chloroform: octanol (24:1) extraction, DNA was precipitated from the aqueous phase by adding an equal volume of CTAB precipitation solution (1\% [wt/vol] CTAB, $50 \mathrm{mM}$ Tris- $\mathrm{HCl} \mathrm{pH} 8.0,10 \mathrm{mM}$ EDTA). DNA was dissolved in $5 \mathrm{ml}$ of a high salt buffer (1 M $\mathrm{NaCl}, 50 \mathrm{mM}$ Tris- $\mathrm{HCl} \mathrm{pH}$ 8.0, $10 \mathrm{mM}$ EDTA), re-precipitated with 0.6 volume of isopropanol, washed with $70 \%$ ethanol, and re-suspended in Tris-EDTA (TE; pH 8.0). Finally the DNA was purified by $\mathrm{CsCl}$ density gradient (Ausubel et al. 1994). The purified DNA was dissolved in TE ( $\mathrm{pH} 8.0)$ to a concentration of $100 \mathrm{ng} / \mathrm{ml}$.

The library was constructed in the lambda vector GEM-12 following the method recommended by the manufacturer (Promega, Madison, WI) with Nd-1 DNA that had been partially digested with $\mathrm{MboI}$ (size range 12 to $20 \mathrm{~kb}$ ). The use of DNA Polymerase I with dATP and dGTP to partially fill in the 
single-strand DNA ends generated by MboI obviated the need to size fractionate the DNA prior to ligation with the supplied GEM-12 vector arms. Ligated DNA (300 ng) was packaged with Gigapack II packaging extracts following the instructions of the manufacturer (Stratagene, La Jolla, CA). The titer of the library was $2.2 \times 10^{6} \mathrm{PFU} / \mathrm{ml}$ prior to amplification (Ausubel et al. 1994). DNA clones were obtained from the library by standard techniques (Ausubel et al. 1994).

\section{RFLP and polymerase chain reaction-based marker analysis.}

RFLP markers prefixed with " $m$ " were lambda clones (Chang et al. 1988) provided by J. Dangl, Cologne, Germany. Those prefixed with "Y" were lambda clones produced during the course of this work, and those prefixed with "g" (Nam et al. 1989) were cosmid clones provided by R. Schmidt and C. Dean, Norwich, UK. In addition to the Nd-1 genomic DNA library created during the course of this study, potential RFLP markers were also isolated from lambda libraries containing DNA from the Ler-1, Nd-0, or Col-0 accessions of Arabidopsis. The Ler-1 library was created in the lambda vector EMBL3 (Stratagene, La Jolla, CA) from partial Sau3A-digested Ler-1 DNA (V. Buchanan-Wollaston, Wye College, UK). The Nd-0 library was created in the lambda vector FIXII (Stratagene) from partial Sau3A-digested Nd-0 DNA (M. Grant, University of Leicester, UK). The Columbia library was created in the lambda vector GEM11 (Promega, Madison, WI) from partial MboIdigested Columbia DNA (C. Koncz, Max Planck Laboratory, Cologne, Germany). Lambda, plasmid, and cosmid DNA was extracted by standard techniques (Ausubel et al. 1994) and radiolabeled with a random primed DNA labeling kit purchased from Pharmacia (St. Albans, UK). Plant DNA was prepared as described for the construction of the Nd-1 DNA lambda library except that purification by $\mathrm{CsCl}$ gradient was omitted. Restriction digests, Southern blotting, and hybridization of probes to DNA followed standard techniques (Ausubel et al. 1994; Church and Gilbert 1984). Typically, 2 to $3 \mu \mathrm{g}$ of plant DNA digested with the appropriate restriction enzyme was used for RFLP analysis.

Primers used to amplify Arabidopsis microsatellite sequences were designed from published information and used according to the polymerase chain reaction (PCR) conditions recommended (Bell and Ecker 1994). For CAPS markers, nccl, gapB, gpal, and $G L 1$, PCR amplification and restriction enzyme digestion of the resulting PCR products were as described by Konieczny and Ausubel (1993). RFLP markers m249, Y3002, and p1C7L were converted into CAPS markers to expedite the analysis of the RI lines. Y3002 and m249 DNA was digested with BamHI or EcoRI and cloned into the plasmid vector pBluescript $\mathrm{SK}^{+}$ (Stratagene, La Jolla, CA) by standard techniques (Ausubel et al. 1994). Subclones of 1 to $2 \mathrm{~kb}$ were selected and, along with p1C7L, their DNA sequence partially determined with a rhodamine dye terminator cycle sequencing kit (Perkin-Elmer, Foster City, CA) and standard T3 and T7 sequencing primers. Cycle sequencing products were analyzed on an ABI PRISM 377 automated sequencing machine (Perkin-Elmer) and primer pairs for PCR amplification designed from the DNA sequence with PrimerSelect (DNASTAR, Madison, WI). For PCR, 25 ng of plant DNA was used in a $25-\mu$ reaction containing $50 \mathrm{mM}$ $\mathrm{KCl}, 10 \mathrm{mM}$ Tris/ $\mathrm{HCl} \mathrm{pH} 8.3,2 \mathrm{mM} \mathrm{MgCl}_{2}, 200 \mu \mathrm{M}$ concentrations of each dNTP, $0.4 \mu \mathrm{M}$ concentrations of each primer, and 1 U Taq DNA polymerase. A Perkin-Elmer 2400 thermocycler was used, and the amplification conditions were as follows: $1 \mathrm{~min}$ at $94^{\circ} \mathrm{C}$, followed by 30 cycles of $30 \mathrm{~s}$ at $94^{\circ} \mathrm{C}$, $30 \mathrm{~s}$ at $55^{\circ} \mathrm{C}, 2 \mathrm{~min}$ at $72^{\circ} \mathrm{C}$, then a final extension at $72^{\circ} \mathrm{C}$ for $10 \mathrm{~min}$. PCR product from half the reaction was digested in a final volume of $40 \mu \mathrm{l}$ containing the appropriate restriction enzyme and the products resolved on a $2.0 \%$ agarose gel. The following primers and restriction enzymes were used: $\mathrm{m} 249$, forward primer 5'-CAG AGA GTG ACC AAA TCT GAA CC-3' reverse primer 5'-GCA TTA TGT TAG ACC AAT GTG C-3', and polymorphism revealed by AciI; p1C7L, forward primer 5'-CTC CCC AAG TAG GCT TCC ATT C-3' reverse primer $5^{\prime}$-GAG TGT TGT TGG CTT TCA TGC AG3', and polymorphism revealed by MseI; Y3002, forward primer 5'-TCC TGT GTG TAG AGA ACG GC-3' reverse primer 5'-TAG CGA GAA AAT ATT GTC TG-3', and polymorphism revealed by $R s a \mathrm{I}$.

\section{Screening YAC and BAC DNA libraries.}

YAC (EG library, Grill and Somerville 1991; yUP library, Ecker 1990) libraries containing DNA from the Columbia (Col-0) accession of Arabidopsis were obtained from the Arabidopsis Biological Resource Center (ABRC) at Ohio State University (Columbus, $\mathrm{OH}$ ). The libraries were received as individual clones stored in a 96-well microtiter dish format. The libraries were replicated and gridded onto positively charged nylon membrane (Biotrans+; ICN, Irvine, CA) for hybridization to DNA probes as described by Gibson and Somerville (1992). Yeast clones containing YACs of interest were identified following hybridization of the nylon membranes to radiolabeled DNA probes according to the method of Church and Gilbert (1984).

Total yeast DNA was prepared by the method of Matallana et al. (1992) and Southern blot analysis with probes from the $R P P 13$ interval was used to confirm the integrity of YAC clones. The vectorette PCR amplification method, as described by Matallana et al. (1992), was used to obtain YAC terminal sequences containing Arabidopsis DNA. Total yeast DNA digested with EcoRV or RsaI was used as the starting material. Clamped homogeneous electric field (CHEF) gel electrophoresis was used to size YAC clones. For this purpose, total yeast chromosomal DNA was prepared by embedding yeast cells in low melting point (LMP) agarose plugs as described by Matallana et al. (1992). Plugs were inserted into the wells of a $1.0 \%$ agarose gel (prepared in $0.5 \times$ TBE [Tris-borate-EDTA] buffer) and sealed with $1.0 \%$ LMP agarose. The gel was electrophoresed in a CHEF apparatus (Bio-Rad, Hercules, CA) at a constant temperature of $14^{\circ} \mathrm{C}$, at $200 \mathrm{~V}$ for $26 \mathrm{~h}$. The voltage switching time was $20 \mathrm{~s}$ initially, ramping to $50 \mathrm{~s}$ at the end of the run. YAC clones were sized against yeast chromosomes and a lambda DNA ladder (New England Biolabs, Beverly, MA).

Filters containing clones from a BAC library of Col-0 DNA (TAM BAC library; Choi et al. 1995) were purchased from ABRC. Radiolabeled DNA probes were hybridized to the membranes under recommended conditions and individual, positive $\mathrm{BAC}$ clones were requested from ABRC. The following clones were identified: TAM3C6 (T1K6), TAM7E6 (T2M6), TAM12D6 (T3L18), TAM15D10 (T4L10), and TAM28E7 (T7M19). The numbers in parentheses are those assigned to the clones based on the new numbering format following incorporation of the TAM and TAMU libraries. DNA was isolated from BAC clones 
by the alkaline lysis method of Woo et al. (1994) and their integrity confirmed by Southern blot analysis with probes from the RPP13 interval. Inverse PCR (IPCR) and plasmid rescue were used to isolate the left and right terminal ends, respectively, of the BAC clones (Woo et al. (1994). For plasmid rescue, BAC DNA was digested with $S a c \mathrm{I}, B a m \mathrm{HI}$, or SphI, and for IPCR with AvaI, BamHI, EcoRI, KpnI, SacI, or SmaI.

\section{ACKNOWLEDGMENTS}

We would like to thank Jeff Dangl (EC-BRIDGE Arabidopsis DNA Stock Centre, Cologne, Germany), Renate Schmidt, Caroline Dean, and Alan Slusarenko for making probes available, and Murray Grant, Vicky Buchanan-Wollaston, and Csaba Koncz for providing genomic libraries. We would also like to thank Elly Speulman and Kevin Williams for useful discussions. This work was supported by the Biotechnology and Biological Sciences Research Council through a grant made under the Plant Molecular Biology Initiative. C. C. was supported by the Turkish Higher Education Council, Faculty of Agriculture, University of Çukurova, Turkey.

\section{LITERATURE CITED}

Ausubel, F. M., Brent, R., Kingston, R. E., Moore, D. D., Seidman, J. G., Smith, J. A., and Struhl, K., eds. 1994. Current Protocols in Molecular Biology. John Wiley and Sons, New York.

Bell, C., and Ecker, J. R. 1994. Assignment of 30 microsatellite loci to the linkage map of Arabidopsis. Genomics 19:137-144.

Bent, A. F., Kunkel, B. N., Dahlbeck, D., Brown, K. L., Schmidt, R., Giraudat, J., Leung, J., and Staskawicz, B. J. 1994. RPS2 of Arabidopsis thaliana: A leucine-rich repeat class of plant disease resistance genes. Science 265:1856-1860.

Bisgrove, S. R., Simonich, M. T., Smith, N. M., Sattler, A., and Innes, R. W. 1994. A disease resistance gene in Arabidopsis with specificity for two different pathogen avirulence genes. Plant Cell 6:927-933.

Botella, M. A., Parker, J. E., Frost, L. N., Bittner-Eddy, P. D., Beynon, J. L., Daniels, M. J., Holub, E. B., and Jones, J. D. G. 1998. Three genes of the Arabidopsis RPP1 complex resistance locus recognise distinct Peronospora parasitica avirulence determinants. Plant Cell 10:18471860.

Buell, C. R., and Somerville, S. C. 1997. Use of Arabidopsis recombinant inbred lines reveals a monogenic and a novel digenic resistance mechanism to Xanthomonas campestris pv. campestris. Plant J. 12:21-29.

Camilleri, C., Lafleuriel, J., Macadrè, C., Varoquaux, F., Parmentier, Y., Picard, G., Caboche, M., and Bouchez, D. 1998. A YAC contig map of Arabidopsis thaliana chromosome 3. Plant J. 14:633-642.

Chang, C., Bowman, J. L., DeJohn, A. W., Lander, E. S., and Meyerowitz, E. M. 1988. Restriction fragment length polymorphism linkage map for Arabidopsis thaliana. Proc. Natl. Acad. Sci. USA 85:68566860.

Choi, S., Creelman, R. A., Mullet, J. E., and Wing, R. A. 1995. Construction and characterization of a bacterial artificial chromosome library of Arabidopsis thaliana. Plant Mol. Biol. 13:124-128.

Church, G. M., and Gilbert, W. 1984. Genomic sequencing. Proc. Natl. Acad. Sci. USA 81:1991-1995.

Dangl, J. L., Holub, E. B., Debener, T., Lehnackers, H., Ritter, C., and Crute, I. R. 1992. Genetic definition of loci involved in Arabidopsispathogen interactions. Pages 393-418 in: Methods in Arabidopsis Research. C. Koncz, N.-H. Chua, and J. Schell, eds. World Scientific Pub., Singapore.

Deslandes, L., Pileur, F., Liaubet, L., Camut, S., Can, C., Williams, K., Holub, E., Beynon, J., Arlat, M. and Marco, Y. 1998. Genetic characterization of RRS1, a recessive locus in Arabidopsis thaliana that confers resistance to the bacterial soilborne pathogen Ralstonia solanacearum. Mol. Plant-Microbe Interact. 11:659-667.

Dixon, M. S., Jones, D. A., Keddie, J. S., Thomas, C. M., Harrison, K., and Jones, J. D. G. 1996. The tomato $C f$-2 disease resistance locus comprises two functional genes encoding leucine-rich repeat proteins. Cell 84:451-459.

Ecker, J. R. 1990. PFGE and YAC analysis of Arabidopsis thaliana.
Methods 1:186-194.

Ellis, J. G., Lawrence, G. J., Ayliffe, M., Anderson, P., Collins, N., Finnegan, J., Frost, D., Luck, J., and Pryor, T. 1997. Advances in the molecular genetic analysis of the flax-flax rust interaction. Annu. Rev. Phytopathol. 35:271-291.

Ellis, J. G., Lawrence, G. J., Finnegan, E. J., and Anderson, P.A. 1995. Contrasting complexity of two rust resistance loci in flax. Proc. Natl. Acad. Sci. USA 92:4185-4188.

Flor, H. H. 1971. Current status of the gene-for-gene concept. Annu. Rev. Phytopathol. 9:275-296.

Gibson, S. I., and Somerville, C. 1992. Chromosome walking in Arabidopsis thaliana using yeast artificial chromosomes. Pages 119-143 in: Methods in Arabidopsis Research. C. Koncz, N.-H. Chua, and J. Schell, eds. World Scientific Pub., Singapore.

Grant, M. R., Godiard, L., Straube, E., Ashfield, T., Lewald, J., Sattler, A., Innes, R. W., and Dangl, J. L. 1995. Structure of the Arabidopsis $R P M 1$ gene enabling dual specificity disease resistance. Science 269: 843-846.

Grill, E., and Somerville, C. 1991. Construction and characterization of a yeast artificial chromosome library of Arabidopsis which is suitable for chromosome walking. Mol. Gen. Genet. 226:484-490.

Hammond-Kosack, K. E., and Jones, J. D. G. 1997. Plant disease resistance genes. Annu. Rev. Plant Physiol. Plant Mol. Biol. 48:575-607.

Hauge, B. M., Hanley, S. M., Cartinhour, S., Cherry, J. M., Goodman, H. M., Koorneef, M., Stam, P., Chang, C., Kempin, S., and Medrano, L. 1993. An integrated genetic/RFLP map of the Arabidopsis thaliana genome. Plant J. 3:745-754.

Holub, E. B. 1997. Organization of resistance genes in Arabidopsis. Pages 5-26 in: The Gene-for-Gene Relationship in Plant Parasite Interactions. I. R. Crute, E. B. Holub, and J. J. Burdon, eds. CAB Int., Wallingford, UK.

Holub, E. B., and Beynon, J. 1997. Symbiology of mouse-ear cress (Arabidopsis thaliana) and Oomycetes. Adv. Bot. Res. 24:228-273.

Holub, E. B., Beynon, J. L., and Crute, I. R. 1994. Phenotypic and genotypic characterization of interactions between isolates of Peronospora parasitica and accessions of Arabidopsis thaliana. Mol. PlantMicrobe Interact. 7:223-239.

Hulbert, S. H. 1997. Structure and evolution of the Rp1 complex conferring rust resistance in maize. Annu. Rev. Phytopathol. 35:293-310.

Islam, M. R., and Shepherd, K. W. 1991. Present status of genetics of rust resistance in flax. Euphytica 55:255-267.

Jones, D. A., Thomas, C. M., Hammond-Kosack, K. E., Balint-Kurti, P. J., and Jones, J. D. G. 1994. Isolation of the tomato Ct-9 gene for resistance to Cladosporium fulvum by transposon tagging. Science 266:789-793.

Joos, H.-J., Mauch-Mani, B., and Slusarenko, A. J. 1996. Molecular mapping of the Arabidopsis locus RPP11, which conditions isolatespecific hypersensitive resistance against downy mildew in ecotype RLD. Theor. Appl. Genet. 92:281-284.

Jørgensen, J. H. 1992. Multigene families of powdery mildew resistance genes in locus mla on barley chromosome 5. Plant Breed. 108:53-59.

Kobe, B., and Deisenhofer, J. 1995. A structural basis of the interaction between leucine-rich repeats and protein ligands. Nature 374:183-186.

Koch, E., and Slusarenko, A. 1990. Arabidopsis is susceptible to infection by a downy mildew fungus. Plant Cell 2:437-445.

Konieczny, A., and Ausubel, F. M. 1993. A procedure for mapping Arabidopsis mutations using co-dominant ecotype-specific PCRbased markers. Plant J. 4:403-410.

Lister, C., and Dean, C. 1993. Recombinant inbred lines for mapping RFLP and phenotypic markers in Arabidopsis thaliana. Plant J. 4: 745-750.

Martin, G. B., Brommonschenkel, S. H., Chunwongse, J., Frary, A., Ganal, M. W., Spivey, R., Wu, T., Earle, E. D., and Tanksley, S. D. 1993. Map-based cloning of a protein kinase gene conferring resistance in tomato. Science 262:1432-1436.

Matallana, E., Bell, C. J., Dunn, P. J., Lu, M., and Ecker, J. R. 1992. Genetic and physical linkage of the Arabidopsis genome: methods for anchoring yeast artificial chromosomes. Pages 144-169 in: Methods in Arabidopsis Research. C. Koncz, N.-H. Chua, and J. Schell, eds. World Scientific Pub., Singapore.

McDowell, J. M., Dhandaydham, M., Long, T. A., Aarts, M. G. M., Goff, S., Holub, E. B., and Dangl, J. L. 1998. Intragenic recombination and diversifying selection contribute to the evolution of downy mildew resistance at the RPP8 locus of Arabidopsis. Plant Cell 10: 1861-1874. 
Meyers, B. C., Chin, D. B., Shen, K. A., Sivaramakrishnan, S., Lavelle, D. O., Zhang, Z., and Michelmore, R. W. 1998. The major resistance gene cluster in lettuce is highly duplicated and spans several megabases. Plant Cell 10:1817-1832.

Mindrinos, M., Katagiri, F., Yu, G.-L., and Ausubel, F. M. 1994. The A. thaliana disease resistance gene RPS2 encodes a protein containing a nucleotide-binding site and leucine-rich repeats. Cell 78:1089-1099.

Nam, H.-G., Giraudat, J., den Boer, B., Moonan. F., Loos, W. D. B., Hauge, B. M., and Goodman, H. M. 1989. Restriction fragment length polymorphism linkage map of Arabidopsis thaliana. Plant Cell 1: 699-705.

Parker, J. E., Coleman, M. J., Szabò, V., Frost, L. N., Schmidt, R., van der Biezen, E. A., Moores, T., Dean, C., Daniels, M. J., and Jones, J. D. G. 1997. The Arabidopsis downy mildew resistance gene RPP5 shares similarity to the Toll and Interleukin-1 receptors with $N$ and $L 6$. Plant Cell 9:879-894.

Parker, J. E., Szabo, V., Staskawicz, B. J., Lister, C., Dean, C., Daniels, M. J., and Jones, J. D. G. 1993. Phenotypic characterization and molecular mapping of the Arabidopsis thaliana locus, RPP5, determining disease resistance to Peronospora parasitica. Plant J. 4:821-831.

Reignault, P., Frost, L. N., Richardson, H., Daniels, M. J., Jones, J. D. G., and Parker, J. E. 1996. Four Arabidopsis RPP loci controlling resistance to the Noco2 isolate of Peronospora parasitica map to re- gions known to contain other $R P P$ recognition specificities. Mol. Plant-Microbe Interact. 9:464-473.

Song, W. Y., Wang, G. L., Chen, L. L., Kim, H. X., Pi, L. Y., Holsten, T., Gardner, J., Wang, B., Zhai, W. X., Zhy, L. H., Fauquet, C., and Ronald, P. 1995. A receptor kinase-like protein encoded by the rice disease resistance gene $\mathrm{Xa}-21$. Science 270:1804-1806.

Thomas, C. M., Jones, D. A., Parniske, M., Harrison, K., Balint-Kurti, P. J., Hatzixanthis, K., and Jones, J. D. G. 1997. Characterization of the tomato $C f-4$ gene for resistance to Cladosporium fulvum identifies sequences that determine recognitional specificity in Cf-4 and Cf- 9 . Plant Cell 9:2209-2224.

Tör, M., Holub, E. B., Brose, E., Musker, R., Gunn, N., Can, C., Crute, I. R., and Beynon, J. L. 1994. Map positions of three loci in Arabidopsis thaliana associated with isolate-specific recognition of Peronospora parasitica (downy mildew). Mol. Plant-Microbe Interact. 7:214-222.

Warren, R. F., Henk, A., Mowery, P., Holub, E. B., and Innes, R. W. 1998. A mutation within the leucine-rich repeat domain of the Arabidopsis disease resistance gene RPS5 partially suppresses multiple bacterial and downy mildew resistance genes. Plant Cell 10:14391452.

Woo, S., Jiang, J., Gill, B. S., Patterson, A. H., and Wing, R. 1994. Construction and characterisation of a bacterial artificial chromosome library of Sorghum bicolor. Nucleic Acids Res. 22:4922-4931. 